\title{
HOW IS ENVIRONMENTAL PERFORMANCE ASSOCIATED WITH ECONOMIC GROWTH? A WORLD CROSS-COUNTRY ANALYSIS
}

\author{
Olimpia Neagu, Ph.D. Associate Professor \\ Doru Ioan Ardelean, Ph.D. Associate Professor \\ Vasile Lazăr, Ph.D. Associate Professor \\ Faculty of Economics, Engineering and Informatics, \\ Vasile Goldiş Western University of Arad, Romania
}

(Received May 2017; Accepted August 2017)

\begin{abstract}
The aim of the paper is to explore the association between environmental performance and income level in the world economy in 2016. Data from Yale University and World Bank are used in a cross-country regression analysis comprising 166 countries. The gross Domestic Product per capita (based in purchased power parity, constant 2011 international dollars) in these countries is positively associated with the environmental performance index (EPI) calculated by Yale and Columbia University in 2016. Furthermore, the causality of this relationship is from GDP per capita to Environmental Performance and both Environmental Health (EH) and Ecosystem Vitality (EV) are positively associated with GDP per capita. Environmental Health (EH) is stronger related to GDP per capita, meaning that investments in public health, sanitation and infrastructure are increasing as countries develop.

Keywords: sustainable development, environmental economics, economic growth, crosssectional models

JEL Codes: Q01, Q50, O40, C21

\section{Introduction}

The growing concern about sustainable development induced in recent years the term of "environmental performance" universally adopted by environmental experts, economists, environmental policy analysts as well as by decision makers. Human activity and economic growth impact on living and non-living systems, including ecosystems, land, air and water. As a reverse, environmental quality (air, water, plants, animals, biodiversity, climate, soils quality) affects our biological lives as well as the efficiency and effectiveness in producing goods and services.

Worldwide environmental degradation makes people, experts and policy makers worried about the issue of the link between economic growth and environmental degradation or performance, since it is generally believed that a high level of environmental performance is associated with a high environmental quality of life and life standard.
\end{abstract}


It is difficult to measure the impact of income or economic growth on environmental performance due to the fact that it has several aspects (water, air, soil, biodiversity, etc.) which must be included and combined in one single construction. Furthermore, in order to be relevant for environmental analysts and for environmental policy makers, any composite index of a country's environmental performance should capture national efforts to protect the natural environment.

The Environmental Performance Index (EPI) calculated by Yale University in cooperation with Columbia University focuses on measurable outcomes that can be linked to environmental policy targets, encopassing 22 environmental indicators.

Noting that there are very few studies focused on exploring the environmentincome relationship based on this index, the intention of the present authors' paper is to highlight the link between the environmental performance expressed through EPI and the income level in the world economy in 2016.

The paper is organised as follows: after the introduction, the section of literature review exposes the main relevant studies for the paper's topic. The methodology and data are described in the third section, the fourth section is dedicated to main findings and the last one contains the paper's conclusions.

\section{Literature review}

The issue of income-environment relationship has been the focus of a huge amount of empirical studies in last 25 years.

Shafik and Bandyopadhyay (1992) explored the relationship between economic growth and environmental quality in 66 countries by analyzing patterns of environmental transformation at different income levels. They looked at eight indicators of environmental quality (deforestation, dissolved oxygen, sulfur dioxide, access to safe water and urban sanitation, carbon emissions, municipal waste, suspended particulate matter, fecal coliform) in response to economic growth in a large number of countries and across time. Income has a significant effect on all environmental quality indicators, but the relation between income and environment is not simple: as incomes rise most indicators decrease initially, except access to safe water and urban sanitation - problems that higher incomes will solve. Countries with high rates of investments and economic growth put pressure on natural resources, particularly in term of pollution, but some indicators, as deforestation and sulfur dioxide tend to improve with higher incomes.

Grossman and Krueger (1995) examined also the relationship between income per capita and various environmental indicators (urban air pollution, oxygen regime in rivers basins, fecal contaminations, and contamination by heavy metals) in 42 countries. They found no evidence that environmental quality deteriorates steadily 
with economic growth and for most environmental indicators economic growth brings an initial phase of deterioration followed by a phase of improvement.

Other authors, such as Islam (1997) demonstrated that there is no rule that environment has to first deteriorate with economic growth and improve later, by estimating the income - environment relationship for Asia and comparing it with the same of other regions of the world. He suggested also that the role of income to explain pollution dynamics is limited.

For a better understanding of the income-environment relationship, its determinants were explored (Panayotou, 1997) and it was decomposed into its structural sources: level effect, composition effect and abatement effect, by using global data. The level and composition effects were found to follow a linear and quadratic evolution and the abatement effect is found to be downward sloping and of backward-J shape (Islam et al., 1998).

This inverted U-shaped pattern identified in several studies as displaying the relationship between income and environmental indicators has given rise to the Environmental Kuznets's Curve Hypothesis. This hypothesis emerged from the initialy theory of Kuznets (1955) stating that the income-inequality relationship should follow an inverse U-shaped along the development process, first rising with industrialisation and then declining, as the labour productivity increases. According to this hypothesis of Kuznets, environmental quality deteriorates in initial phase of growth and then improves at high levels of income.

A vast empirical literature dedicated to Environmental Kuznets's Curve captures the scale, composition, income and technique effects using simple or multiple variables models and various econometric techniques where environmental variables (i.e. pollution, water quality, energy use, biodiversity loss, municipal waste, ecological footprint, deforestation, etc.) are dependent variables and independent variables are income, income squared or income cube (Holtz-Eakin and Selden, 1992; Selden and Song, 1994; Selden and Song, 1994, 1995; Shafiq, 1994; Grossman and Krueger, 1995; Cole et al., 1997; Moomaw and Unruh, 1997; Stern, 1998; de Bruyn et al., 1998; Munasinghe, 1999; Stern and Common, 2001; Harbaugh et al., 2002; Bimonte, 2002; Perman and Stern, 2003; Lee and List, 2004; Dinda, 2004 and 2005; Pertinelli and Strobl, 2005; Shen, 2006; Saboori et al., 2011; Shahbaz et al.,2012; Taguchi, 2012; Tiwari et al. 2013).

There are also a group of studies where no validity of EKC was found (i.e. Seppälä et al. 2001; Stern, 2004; Caviglia-Harris et al. 2009), as well as studies concluding that the Kuznets curves can be true for a cross-section of countries at a specific point in time (Booth, 2017) or founding an inverse global environmental Kuznets curve (Jha and Murthy, 2003). Other studies are concerned on globalization effects 
on environmental Kuznets Curve (i.e.Tisdell, 2001) or found a reverse Kuznets Curve (i.e.Bulte and van Soest, 2001).

The main problem of all these studies was to measure the environment degradation and several statistical indicators were proposed and used: depletion and degradation of forest, water, land resources, air pollution, greenhouse gases pollution, etc. Several attempts were made to construct composite indexes to express the environmental quality or depreciation, such as: Environmental Quality Index (EQI), Environmental Indicators developed by OECD and Environmental Performance Index (EPI).

EQI was developed for all counties in the United States. It uses indicators from the chemical, natural, built, and social environment, based on data collected and monitorised by US Environmental Protection Agency (EPA).

OECD (2003) developed a set of environmental indicators regarding: climate change, ozone layer depletion, eutrophication, acidification, toxic contamination, urban environmental quality, biodiversity, cultural landscapes, waste, water resources, forest resources, fish resources, soil degradation, material resources and other socio-economic indicators. A part of them are used jointly with the Statistical Office of the European Commission (Eurostat).

The UNDP's experts include in the concept of Environment Sustainability the following statistical indicators: Renewable energy consumption (\% of total final energy consumption), Carbon dioxide emissions (tones per capita), Forest area (\% of total land), Fresh water withdrawals (\% of renewable water resources) (UNDP, 2016).

The EPI builds on measures relevant to two core objectives: (a) reducing environmental stress to human health (the environmental health) and (b) protecting ecosystems and natural resources (the ecosystem vitality). The present paper used this index to explore the income-environment relationship; therefore this index is exposed in the second section, Data and Methodology.

\section{Data and methodology}

The paper uses regressional analysis techniques in order to put in evidence the association between environmental performance and income level in the world economy in 2016. Specifically, a cross-country regression is developed, taking into consideration the environmental performance as dependent variable and the level of economic development as independent variable.

For the use of this paper, the environmental performance is expressed by the metrics calculated by the Yale Data-Driven Environmental Group at Yale University and Center for International Earth Science Information Network at Columbia University in collaboration with the Samuel Family Foundation, McCall 
MacBain Foundation, and the World Economic Forum, namely the Environmental Performance Index (EPI). It ranks countries' performance in two areas: protection of human health and protection of ecosystems. It scores national performance in nine issue areas comprised of 22 indicators measuring the country proximity to meet the internationally established targets and to compare their environmental performance. EPI has two components: Environmental Health (EH) and Ecosystem Vitality (EV). The first component comprises of health impacts expressed by environmental risk exposure (risk of water and air pollution to human health) air quality (population exposure to PM 2.5 and health risk from PM 2.5 exposure, population whose exposure is above WHO thresholds, population exposure to NO2) and water and sanitation (exposure to unsafe sanitation and population lacking access to sanitation, exposure to insafe water quality and population lacking access to drinking water). The second component includes: water resources (wastewater treatment), agriculture (nitrogen use efficiency and nitrogen balance), forests (change in forest cover), fisheries (fishing stock overexploited and collapsed) biodiversity and habitat (protected terrestrial biome area, marine protected areas, species under protection), climate and energy (performance in change in $\mathrm{CO} 2$ emissions per unit GDP, change in $\mathrm{CO} 2$ emissions from electricity and heat production). The level of aggregation is $50 \%$ for each component (Hsu et al., 2016).

The economic development is expressed by GDP per capita based on purchase power parity (PPP) constant 2011 constant international dollars extracted from World Bank Database, for 166 countries corresponding to those the Environmental Performance Index is calculated by Yale and Columbia University. The values of EPI, EH, EV and GDPper capita for the 166 economies are exposed in Annex 1.

We analyse the stochastic dependence between environmental performance and economic development through a regression equation:

$y=f(x)+\varepsilon$

where $y$ is expressed by EPI, $x$ is measured by GDP per capita and $\varepsilon$ is the significance error.

We presume that there is linear dependence between the two variables and we intend to check this assumption. In a graphical representation (Figure 1) we notice that the behaviour of the function $y$ is quadratic, not linear, it never reach a maximum or minimum y value and that the impact of independent variable $(x)$ on dependent variable $(y)$ decreases as the value of $y$ increases. 


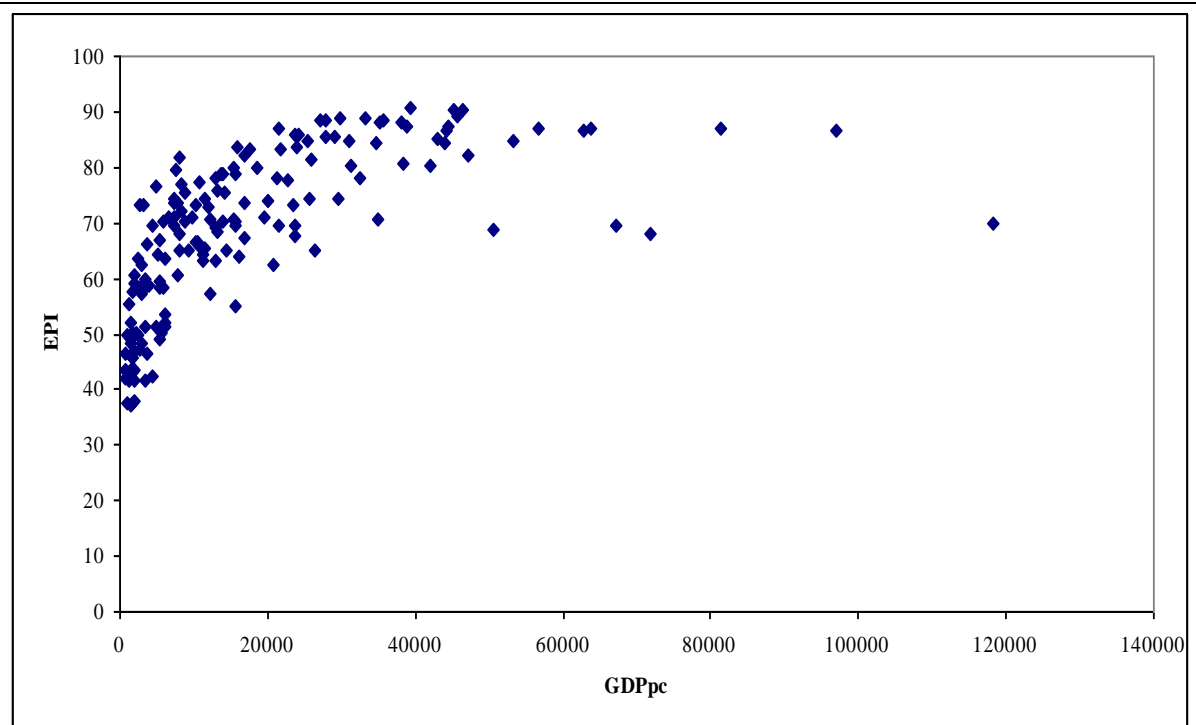

Figure 1 GDP per capita (PPP) versus EPI in the world economy, 2016

Source: authors' own computation based on World Bank and Yale and Columbia University data

Taking into consideration the above conclusions, we choose a linear-log model, as follows:

$$
E P I_{i}=\alpha+\beta \cdot \log G D P p c_{i}+\varepsilon
$$

where $E P I_{i}$ means Environmental Performance Index for the country $i, G D P p c_{i}$ is the Gross Domestic Produc per capita for country $i, \alpha$ is a constant, $\beta$ is the regression coeficient and $\varepsilon$ is the significance error.

In order to explore in detail the impact of economic growth we use the equation 2 for the two compoments of Environmental Performance Index:

Environmental Health (EH):

$$
E H_{i}=\alpha_{h}+\beta_{h} \cdot \log G D P p c_{i}+\varepsilon_{h}
$$

Ecosytem Vitality (EV):

$$
E V_{i}=\alpha_{v}+\beta_{v} \cdot \log G D P p c_{i}+\varepsilon_{v}
$$

We estimated the regression parameters of equations (2)-(4) by using the OLS method within the EViews 9.0 software.

\section{Main findings}

The estimated equation 2 is the following:

20 DE GRUYTER OPEN
Studia Universitatis "Vasile Goldis" Arad. Economics Series Vol 27 Issue 3/2017 ISSN: 1584-2339; (online) ISSN: 2285 - 3065

Web: publicatii.uvvg.ro/index.php/studiaeconomia.Pages 15 - 32 
Neagu O., Ardelean D.I., Lazăr V. (2017)

How is environmental performance associated with economic growth? A world cross-country analysis

$$
E P I=-25.48974+23.4682 \cdot \log G D P p c
$$

$$
\text { (0.0000) (0.0000) }
$$

We can follow the dependence of EPI to GDPpc in the Figure 2:

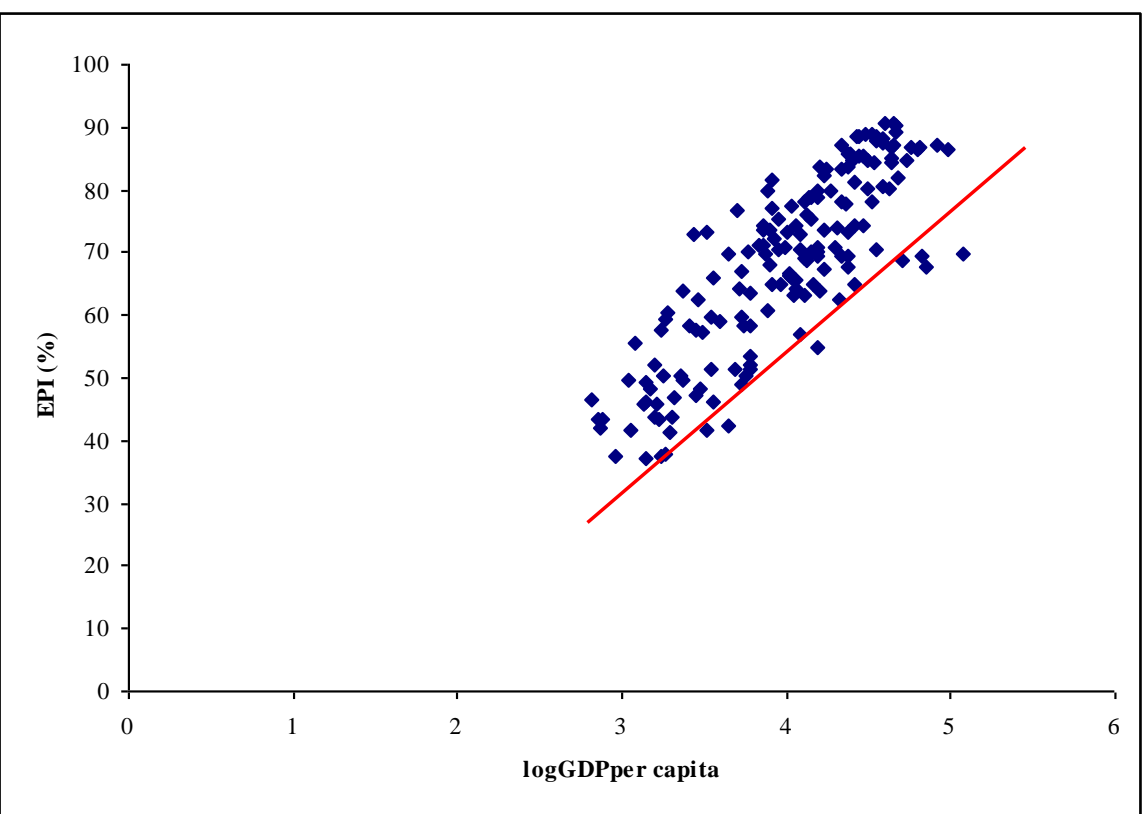

Figure 2 EPI versus logGDP per capita in the world economy, 2016

Source: authors' own computation based on World Bank and Yale and Columbia University data

We notice that, mainly, all examined countries are grouped around the red regression line (Figure 2), but according to the Annex 2, the first 10 countries ranked by GDP per capita are not the first when the ranking criterion is EPI. Finland, Iceland and Sweden are on the first positions according to the values of EPI, but according to GDP level, they are positioned on Finland on the 10-th, Iceland on the 14-th and Sweden on the 12-th places. Qatar, Brunei, United Arab Emirates, the most rich countries in the world have modest environmental performances.

The statistical cross-country model (Table 1) can be validated due to the fact that the value of Prob (F-statistic) is 0.000 lower than 0.05, the significance threshold. The value of Prob. for the constant $\mathrm{C}$ and the coefficient of logGDPpc is 0.000 $(<0.05)$.

DE GRUYTER OPEN 
Table 1- Estimation of equation 2

Dependent Variable: EPI

Method: Least Squares

Date: 07/12/17 Time: 23:02

Sample: 1166

Included observations: 166

\begin{tabular}{lrcrc}
\hline \hline \multicolumn{1}{c}{ Variable } & Coefficient & \multicolumn{1}{c}{ Std. Error } & t-Statistic & Prob. \\
\hline \multicolumn{1}{c}{ C } & -25.48974 & 4.746141 & -5.370625 & 0.0000 \\
\multicolumn{1}{c}{ LOGGDPPC } & 23.46822 & 1.181013 & 19.87127 & 0.0000 \\
\hline \hline R-squared & 0.706549 & Mean dependent var & 68.02620 \\
Adjusted R-squared & 0.704760 & S.D. dependent var & 14.58977 \\
S.E. of regression & 7.927495 & Akaike info criterion & 6.990526 \\
Sum squared resid & 10306.61 & Schwarz criterion & 7.028020 \\
Log likelihood & -578.2137 & Hannan-Quinn criter. & 7.005745 \\
F-statistic & 394.8674 & Durbin-Watson stat & 1.958068 \\
Prob(F-statistic) & 0.000000 & & \\
\hline \hline
\end{tabular}

Source: authors' computation by using EViews 9.0 software

The determination coefficient (R-squared) is 0.706549 meaning that $70.65 \%$ of the variation of EPI can be explained by the variation of logGDP per capita. The value of adjusted R-squared (0.704760) is close to the R-squared meaning that our sample is relevant for an accurate representation of the reality.

The parameter $\beta$ has the value of 23.46822 showing that for an increase of percetange point of GDP per capita, EPI will increase with 23.46822 units, if other factors are remaining constant.

In order to test the heteroskedasticity of errors, we used the White test (Table 2).

Table 2-Heteroskedasticity test for equation 2

Heteroskedasticity Test: White

\begin{tabular}{llll}
\hline \hline F-statistic & 1.212489 & Prob. F(2,163) & 0.3001 \\
Obs*R-squared & 2.433408 & Prob. Chi-Square(2) & 0.2962 \\
Scaled explained SS & 2.230022 & Prob. Chi-Square(2) & 0.3279 \\
\hline \hline
\end{tabular}

Source: authors' computation by using EViews 9.0 software 
The value of Obs*R-squared $(1.2124289)<\chi_{0,05 ; 2}^{2}=5.99$ meaning that the null hypothesis is accepted and the errors are homoskedastic, for a significance level of $5 \%$ : the variation of dependent variable being constant for any level of independent variables.

We intend to check the autocorrelation of errors by using the Breusch-Godfrey Serial Correlation LM Test (Table 3). The value of Obs*R-squared (1.294041) < $\chi_{0,05 ; 2}^{2}=5.99$, meaning that the null hypothesis is accepted and the errors are independent (not autocorrelated).

Table 3- Errors autocorrelation detection

Breusch-Godfrey Serial Correlation LM Test:

\begin{tabular}{llll}
\hline \hline F-statistic & 0.636390 & Prob. F(2,162) & 0.5305 \\
Obs*R-squared & 1.294041 & Prob. Chi-Square(2) & 0.5236 \\
\hline \hline
\end{tabular}

Source: authors' computation by using EViews 9.0 software

In order to check the causality sense of the relationship between logGDP per capita and environmental performance index (EPI), we used the Granger causality test from Eviews 9.0. The result displayed in the Table 4 show us that the value of Fstatistic (36.4485) is higher than $F_{0,05 ; 1, \infty}=3.84$, meaning that the null hypothesis is rejected and $\log$ GDP per capita does cause EPI.

\section{Table 4-Causality test}

Pairwise Granger Causality Tests

Date: 07/12/17 Time: 23:06

Sample: 1166

Lags: 2

\begin{tabular}{lccc}
\hline \hline Null Hypothesis: & Obs & F-Statistic & Prob. \\
\hline \hline LOGGDPPC does not Granger Cause EPI & 164 & 36.4485 & 9. E-14 \\
EPI does not Granger Cause LOGGDPPC & & 0.68069 & 0.5077 \\
\hline
\end{tabular}

Source: authors' computation by using EViews 9.0 software

Both Environmental Health (EH) and Ecosystem Vitality (EV) are positively associated with GDP per capita (Figure 3a) -b) and Table 5). The link is stronger for Environmental Health, R-squared is 0.684909 compared to 0.380693 for 
Ecosystem Vitality. The dispersion of Ecosystem Vitality in the group of examined countries is higher than the Environmental Health (Figure 3a and Figure 3b), reflecting that, in terms of natural resources management and biodiversity protection, the world economy should be more effective and more concern should be given by national authorities to preserve and maintain the vitality of natural heritage as the economic activities evolves.

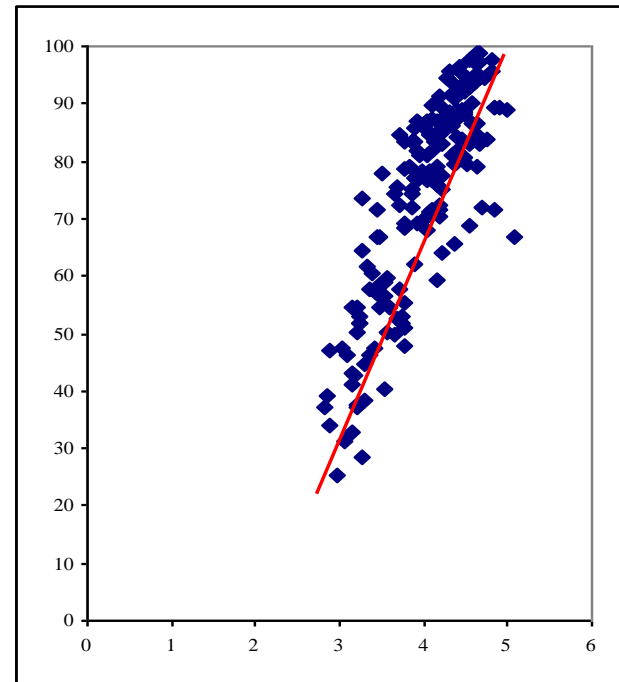

Figure 3a) Environmental Health and logGDP per capita

Source: authors' own computation based on World Bank and Yale and Columbia University data

For both variables (EH and EV), the cross-country regression model can be validated (Table 5), due to the fact that the value of Prob(F-statistic) is $0.000(<0.05)$.

In the case of Environmental Health (EH), a percentage change of GDP per capita can lead to an increase of 28.50553 units of EH. The influence of GDP per capita on the change of Ecosystem Vitality (EV) is weaker, a change of one percentage point of GDP per capita is leading to an increase of EV with 18.43201 units. 
Neagu O., Ardelean D.I., Lazăr V. (2017)

How is environmental performance associated with economic growth? A world cross-country analysis

\begin{tabular}{|c|c|c|c|c|c|c|c|}
\hline \multicolumn{8}{|c|}{$\begin{array}{c}\text { Table } 5 \text {-The relationship between EH, EV and logGDP per capita in the world } \\
\text { economy, } 2016\end{array}$} \\
\hline \multicolumn{4}{|c|}{ Dependent Variable: EH } & \multicolumn{4}{|c|}{ Dependent Variable: EV } \\
\hline \multicolumn{4}{|c|}{ Method: Least Squares } & \multicolumn{4}{|c|}{ Method: Least Squares } \\
\hline \multicolumn{4}{|c|}{ Date: 07/12/17 Time: 23:08 } & \multicolumn{4}{|c|}{ Date: 07/12/17 Time: 23:11 } \\
\hline \multicolumn{4}{|l|}{ Sample: 1166} & \multicolumn{4}{|l|}{ Sample: 1166} \\
\hline \multicolumn{4}{|c|}{ Included observations: 166} & \multicolumn{4}{|c|}{ Included observations: 166} \\
\hline Variable & Coefficient & Std. Error $\mathrm{t}$-Statistic & Prob. & Variable & Coefficient & Std. Error & Prob. \\
\hline $\mathrm{C}$ & -40.57450 & $6.067285 \quad-6.687424$ & 0.0000 & $\mathrm{C}$ & -10.40868 & -1.410890 & 0.1602 \\
\hline LOGGDPPC & 28.50553 & $1.509762 \quad 18.88081$ & 0.0000 & LOGGDPPC & 18.43201 & 1.835762 & 0.0000 \\
\hline R-squared & 0.684909 & Mean dependent var & 73.01404 & $\begin{array}{l}\text { R-squared } \\
\text { Adjusted R- }\end{array}$ & 0.380693 & Mean dependent var & 63.03904 \\
\hline Adjusted R-squared & d 0.682988 & S.D. dependent var & 17.99915 & squared & 0.376917 & S.D. dependent var & 15.61078 \\
\hline S.E. of regression & 10.13421 & Akaike info criterion & 7.481685 & $\begin{array}{l}\text { S.E. of regression } \\
\text { Sum squared }\end{array}$ & 12.32247 & Akaike info criterion & 7.872700 \\
\hline Sum squared resid & 16843.15 & Schwarz criterion & 7.519179 & resid & 24902.28 & Schwarz criterion & 7.910194 \\
\hline Log likelihood & -618.9799 & Hannan-Quinn criter. & .7 .496904 & Log likelihood & -651.4341 & Hannan-Quinn criter. & 7.887919 \\
\hline F-statistic & 356.4851 & Durbin-Watson stat & 1.989741 & F-statistic & 100.8122 & Durbin-Watson stat & 2.033616 \\
\hline Prob(F-statistic) & 0.000000 & & & Prob(F-statistic) & 0.000000 & & \\
\hline $\begin{array}{r}E H=-40.57 \\
(6.0\end{array}$ & $\begin{array}{l}7450+28 \\
0672)\end{array}$ & $\begin{array}{l}8.50533 \cdot \log G L \\
(1.5097)\end{array}$ & $\mathrm{DPpc}$ & $E V=-10.4$ & $868+18$ & $\begin{array}{l}3201 \cdot \log G D P p c \\
8357)\end{array}$ & \\
\hline
\end{tabular}

Source: authors' computation by using EViews 9.0 software

\section{Conclusions}

The aim of the paper was to explore the association between environmental performance and the level of income in the world economy in 2016.

We found a positive strong association between economic growth expressed by log GDP per capita and the values of environmental performance index (EPI) in 2016, in the world economy (166 countries). The cross-country model is statistically validated and reflects the beneficial influence of GDP per capita on the environmental performance, suggesting that as wealth increases, national environmental performance improves.

Both Environmental Health (EH) and Ecosystem Vitality (EV) are positively associated with GDP per capita, but Environmental Health (EH) is stronger related to GDP per capita, meaning that investments in public health, sanitation and infrastructure are increasing as countries develop.

Ecosystem Vitality (EV) scores are more dispersed in their relationship with GDP per capita. For example, rich countries as Qatar, Kuwait, Oman and United Arab

DE GRUYTER OPEN
Studia Universitatis "Vasile Goldis" Arad. Economics Series Vol 27 Issue 3/2017 ISSN: 1584-2339; (online) ISSN: 2285 - 3065 
Emirates underperform on their environmental protection to other wealth and developed countries.

The limits of the study consist on the fact that the analysis is made only for one year, 2016. A combined, across time and across country, analysis would highlight more details of the link between environmental performance and economic growth in the world and to show how if there is a difference on how the economic growth rate is associated to the environmental performance in developed and developing countries. Another direction to which the research could be extended is a crosscountry comparison of costs to reach a certain environmental performance and rate depending to the GDP per capita, as Ardelean and David (2013) suggested in their paper.

Our findings are relevant for national governments from developed and developing countries alike when they design their public environmental policies meant to preserve and maintain the natural heritage and to improve the ecosystem and natural resources management.

\section{Acknowledgment}

This paper was supported by the project "Natural resources and sustainable development of Oaș area, county of Satu Mare, funded by UEFISCDI (Executive Agency for Higher Education, Research, Development and Innovation Funding - National Plan for Research, Development and Innovation 2007-2014, NP II, Human Resources Program, Subprogram "Young research teams", contract no. 332/1.10.2015 (PN II-RU-TE-2014-4-1552).

\section{References}

1. Ardelean, D.I., David, D. (2013). The reflection of the cost-efficiency coefficient of the environment policies in the European Union and the Member States. Studia Universitatis "Vasile Goldiș" Arad, Economic Series, Vol.23, Issue 3, pp.14-20.

2. Bertinelli, L., Strobl, E.(2005). The environmental Kuznets curve semi-parametrically revisited. Economics Letters, Vol.88, pp.350-357.

3. Bimonte, S.(2002). Information access, income distribution, and the Environmental Kuznets Curve. Ecological Economics, Vol.41, Issue 1, pp.145- 156.

4. Booth, H.(2017).The Environmental Kuznets Curve. The validity of Kuznets Curve and its Policy Implications. World Economics, Vol.18, No.1, pp.145-152.

5. Bulte, E.H., van Soest, D.P. (2001). Environmental degradation in developing countries: households and the (reverse) environmental Kuznets curve. Journal of Development Economics, Vol.65, pp.225- 235.

6. Cole, M.A., Rayner, A.J., Bates, J.M. (1997). The Environmental Kuznets Curve: an empirical analysis. Environment and Development Economics, Vol.2, pp.401-416. 
7. Caviglia-Harris, J.L., Chambers, D., and Kahn, J.R.(2009). Taking the 'U' out of Kuznets- A Comprehensive analysis of the EKC and environmental degradation. Ecological Economics, Vol. 68, pp. 1149-1159.

8. de Bruyn, S.M., van den Bergh, J.C.J.M., Opschoor, J.B.(1998). Economic growth and emissions: reconsidering the empirical basis of environmental Kuznets curves. Ecological Economics, Vol.25, pp.161-175.

9. Dinda, S. (2004). Environmental Kuznets Curve Hypothesis: A Survey. Ecological Economics, Vol.49, Issue 4, pp.431-455.

10. Dinda, S. (2005). A theoretical basis for the environmental Kuznets curve. Ecological Economics, Vol.53, pp.403-413.

11. Grossman G. and Krueger, A. (1995). Economic Growth and the Environment. The Quarterly Journal of Economics, Vol.110, Issue 2, pp.353-377.

12. Holtz-Eakin, D., Selden, T.M. (1992). Stoking the fires? CO2 emissions and economic growth. NBER Working Paper 4248.

13. Harbaugh, W., Levinson, A., Wilson, D. (2002). Re-examining the empirical evidence for an environmental Kuznets curve. The Review of Economics and Statistics, Vol. 84, pp.541-551.

14. Hsu, A. et al. (2016). 2016 Environmental Performance Index. New Haven, CT: Yale University. Available: www.epi.yale.edu. Accessed 17 June 2017.

15. Islam, N. (1997). Income-Environment Relationship. How different is Asia? Asian Development Review, Vol.15.No.1, pp.18-51.

16. Islam, N., Vincent, J., Panayotou, T. (1998). Unveiling the Income-Environment Relationship: An Exploration into the Determinants of Environmental Quality. Available at: http://economics.emory.edu/home/documents/workingpapers/islam _98_12_paper.pdf Accessed 10 July 2017.

17. Jha, R. \& Murthy. KVB (2003).An Inverse Global Environmental Kuznets Curve. Journal of Comparative Economics, Vol.31, Issue 2, pp. 352-368.

18. Kuznets, S. (1955). Economic growth and economic inequality. American Economic Review, Vol.45, pp.1-28.

19. Lee, J., List, J.A. (2004). Examining trends of criteria air pollutants: ere the effects of government intervention transitory?. Environmental and Resource Economics, Vol.29, 21-37

20. Moomaw, W.R., Unruh, G.C. (1997). Are Environmental Kuznets curves misleading us? The case of $\mathrm{CO} 2$ emissions. Environment and Development Economics, Vol.2, pp.451-463.

21. Munasinghe, M. (1999). Is environmental degradation an inevitable consequence of economic growth: tunneling through the environmental Kuznets curve. Ecological Economics, Vol.29, Issue 1, pp. 89 - 109.

22. OECD (2003). OECD Environmental Indicators. Development, Measurement and Use. Available at: https://www.oecd.org/env/indicators-modelling-outlooks/24993546.pdf Accessed 1 July 2017.

Studia Universitatis "Vasile Goldis" Arad. Economics Series Vol 27 Issue 3/2017 ISSN: 1584-2339; (online) ISSN: 2285 - 3065 
23. Panayotou, T. (1997). Demystifying the Environmental Kuznets Curve: Turning a Black Box into a Policy Tool. Available at: http://www.cid.harvard.edu/archive/esd/pdfs/iep/ 643.pdf Accessed 4 July 2017.

24. Perman, R., Stern, D.I. (2003). Evidence from panel unit root and cointegration tests that the Environmental Kuznets Curve does not exist. The Australian Journal of Agricultural and Resource Economics, Vol.47, pp.325-347

25. Saboori, B., Sulaiman, J., and Mohd, S.(2011).Economic growth and CO 2 emissions in Malaysia: a cointegration analysis of the environmental Kuznets curve. Energy Policy, Vol.51, pp.184-191.

26. Selden, T.M., Song, D. (1994). Environmental quality and development: is there a kuznets curve for air pollution emissions?. Journal of Environmental Economics and Management, Vol. 27, Issue2, pp.147-162.

27. Selden, T.M., Song, D. (1995). Neoclassical growth, the J curve for abatement and the inverted U curve for pollution. Journal of Environmental Economics and Management, Vol.29, Issue 2, pp.162- 168.

28. Shahbaz, M., Lean, H.H., and Shabbir, M.S. (2012).Environmental Kuznets Curve Hypothesis in Pakistan: Cointegration and Granger Causality. Renewable and Sustainable Energy Reviews, Vol 16, pp. 2947-2953.

29. Shafik, N. and Bandyopadhyay, S. (1992).Economic Growth and Environmental Quality-Time Series and Cross-Country Evidence.World Bank Policy Research Working Paper, WPS 904.

30. Shafik, N. (1994). Economic development and environmental quality: an econometric analysis. Oxford Economic Papers, Vol.46, pp.757-773.

31. Shen, J. (2006).A simultaneous estimation of Environmental Kuznets Curve: Evidence from China. China Economic Review, Vol 17, pp. 383-394.

32. Seppälä, T., Haukioja, T., and Kaivo-oja, J.(2001).The EKC Hypothesis Does Not Hold for Direct Material Flows: Environmental Kuznets Curve Hypothesis Tests for Direct Material Flows in Five Industrial Countries. Population and Environment, Vol 23, Issue2, pp. 217-238.

33. Stern, D.I. (1998). Progress on the environmental Kuznets curve?.Environment and Development Economics Vol.3, Issue 2, pp.173-196.

34. Stern, D.I., Common, M.S.(2001). Is there an environmental Kuznets curve for sulphur?. Journal of Environmental Economics and Management, Vol.41, pp.162-178.

35. Stern, D.I.(2004). The Rise and Fall of Environmental Kuznets Curve.World Development, Vol.32, No.8, pp.1418-1439.

36. Taguchi, H.(2012).The Environmental Kuznets Curve in Asia: The Case of Sulphur and Carbon Emissions. Asia-Pacific Development Journal, Vol 19, pp. 77-92.

37. Tisdell, C. (2001). Globalisation and sustainability: environmental Kuznets curve and the WTO. Ecological Economics, Vol.39, Issue 2, pp.185- 196.

38. Tiwari, A.K., Shahbaz, M., and Hye, Q.M.A. (2013). The Environmental Kuznets Curve and the Role of Coal Consumption in India: Cointegration and Causality Analysis in an Open Economy. Renewable and Sustainable Energy Reviews, Vol 18, pp. 519-527. 
Neagu O., Ardelean D.I., Lazăr V. (2017)

How is environmental performance associated with economic growth? A world cross-country analysis

39. UNDP.(2016).Human Development Report 2016. Human Development for Everyone. Washington DC, USA.

40. http://epi.yale.edu/reports/2016-report. Accessed 30 June 2017

41. http://data. worldbank.org/indicator/NY.GDP.PCAP.PP.KD?view=chart.

Accessed 30.06.2017

Annex 1- EPI, EH, EV and GDP per capita in the world economy in 2016

\begin{tabular}{|c|c|c|c|c|c|c|}
\hline Rank & Country & EPI & EH & $\mathbf{E V}$ & GDP pc & $\log$ GDPpc \\
\hline 1 & Qatar & 69,94 & 66,79 & 73,1 & $118.215,30$ & 5,0727 \\
\hline 2 & Luxembourg & 86,58 & 88,88 & 84,29 & $97.018,66$ & 4,9869 \\
\hline 3 & Singapore & 87,04 & 89,35 & 84,74 & $81.443,36$ & 4,9109 \\
\hline 4 & Brunei Darussalam & 67,86 & 89,33 & 46,39 & $71.788,78$ & 4,8561 \\
\hline 5 & United Arab Emirates & 69,35 & 71,43 & 67,28 & $67.133,07$ & 4,8269 \\
\hline 6 & Norway & 86,9 & 97,82 & 75,98 & $63.810,79$ & 4,8049 \\
\hline 7 & Ireland & 86,6 & 95,6 & 77,61 & $62.828,34$ & 4,7982 \\
\hline 8 & Switzerland & 86,93 & 83,78 & 90,09 & $56.625,14$ & 4,7530 \\
\hline 9 & United States of America & 84,72 & 94,41 & 75,03 & $53.272,52$ & 4,7265 \\
\hline 10 & Saudi Arabia & 68,63 & 72,03 & 65,22 & $50.458,17$ & 4,7029 \\
\hline 11 & Netherlands & 82,03 & 82,85 & 81,21 & $47.128,31$ & 4,6733 \\
\hline 12 & Sweden & 90,43 & 97,29 & 83,57 & $46.441,21$ & 4,6669 \\
\hline 13 & Denmark & 89,21 & 94,29 & 84,12 & $45.686,48$ & 4,6598 \\
\hline 14 & Iceland & 90,51 & 98,67 & 82,35 & $45.276,45$ & 4,6559 \\
\hline 15 & Australia & 87,22 & 98,71 & 75,73 & $44.414,03$ & 4,6475 \\
\hline 16 & Austria & 86,64 & 86,41 & 86,87 & $44.143,70$ & 4,6449 \\
\hline 17 & Germany & 84,26 & 84,66 & 83,87 & $44.072,39$ & 4,6442 \\
\hline 18 & Canada & 85,06 & 95,15 & 74,96 & $43.087,76$ & 4,6344 \\
\hline 19 & Belgium & 80,15 & 79,1 & 81,21 & $41.945,69$ & 4,6227 \\
\hline 20 & Finland & 90,68 & 97,23 & 84,13 & $39.422,65$ & 4,5957 \\
\hline 21 & United Kingdom & 87,38 & 93,85 & 80,92 & $38.901,05$ & 4,5900 \\
\hline 22 & Japan & 80,59 & 86,59 & 74,58 & $38.239,77$ & 4,5825 \\
\hline 23 & France & 88,2 & 89,97 & 86,44 & $38.058,87$ & 4,5805 \\
\hline 24 & Malta & 88,48 & 92,83 & 84,13 & $35.694,04$ & 4,5526 \\
\hline 25 & New Zealand & 88 & 97,81 & 78,19 & $35.269,10$ & 4,5474 \\
\hline 26 & South Korea & 70,61 & 68,85 & 72,37 & $34.985,85$ & 4,5439 \\
\hline 27 & Italy & 84,48 & 82,83 & 86,14 & $34.620,13$ & 4,5393 \\
\hline 28 & Spain & 88,91 & 94,57 & 83,24 & $33.261,08$ & 4,5219 \\
\hline 29 & Israel & 78,14 & 79,43 & 76,85 & $32.612,69$ & 4,5134 \\
\hline 30 & Cyprus & 80,24 & 88,59 & 71,9 & $31.195,51$ & 4,4941 \\
\hline 31 & Czech Republic & 84,67 & 80,81 & 88,53 & $31.071,75$ & 4,4924 \\
\hline 32 & Slovenia & 88,98 & 88,32 & 89,65 & $29.803,45$ & 4,4743 \\
\hline 33 & Trinidad and Tobago & 74,34 & 92,2 & 56,47 & $29.578,96$ & 4,4710 \\
\hline 34 & Slovakia & 85,42 & 83,77 & 87,07 & $29.156,09$ & 4,4647 \\
\hline 35 & Lithuania & 85,49 & 89,13 & 81,86 & $27.904,10$ & 4,4457 \\
\hline 36 & Estonia & 88,59 & 95,26 & 81,91 & $27.735,14$ & 4,4430 \\
\hline 37 & Portugal & 88,63 & 96,55 & 80,7 & $27.006,87$ & 4,4315 \\
\hline 38 & Seychelles & 64,92 & 92,85 & 36,99 & $26.319,16$ & 4,4203 \\
\hline 39 & Poland & 81,26 & 80,54 & 81,98 & $26.003,01$ & 4,4150 \\
\hline 40 & Malaysia & 74,23 & 84,21 & 64,25 & $25.660,46$ & 4,4093 \\
\hline
\end{tabular}

DE GRUYTER OPEN
Studia Universitatis "Vasile Goldis" Arad. Economics Series Vol 27 Issue 3/2017 ISSN: 1584-2339; (online) ISSN: 2285 - 3065

Web: publicatii.uvvg.ro/index.php/studiaeconomia.Pages $15-32$ 
STUDIA UNIVERSITATIS ECONOMICS SERIES

"Vasile Goldiş" Western University of Arad

Neagu O., Ardelean D.I., Lazăr V. (2017)

How is environmental performance associated with economic growth? A world cross-country analysis

\begin{tabular}{|c|c|c|c|c|c|c|}
\hline 41 & Hungary & 84,6 & 81,89 & 87,3 & $25.381,29$ & 4,4045 \\
\hline 42 & Greece & 85,81 & 89,09 & 82,54 & $24.263,88$ & 4,3850 \\
\hline 43 & Russia & 83,52 & 87,06 & 79,98 & $24.026,00$ & 4,3807 \\
\hline 44 & Latvia & 85,71 & 91 & 80,42 & $23.712,09$ & 4,3750 \\
\hline 45 & Turkey & 67,68 & 79,6 & 55,76 & $23.679,40$ & 4,3744 \\
\hline 46 & Equatorial Guinea & 69,59 & 65,42 & 73,77 & $23.671,40$ & 4,3742 \\
\hline 47 & Kazakhstan & 73,29 & 88,42 & 58,15 & $23.419,91$ & 4,3696 \\
\hline 48 & Chile & 77,67 & 93,23 & 62,11 & $22.706,72$ & 4,3562 \\
\hline 49 & Romania & 83,24 & 81,19 & 85,28 & $21.647,81$ & 4,3354 \\
\hline 50 & The Bahamas & 69,34 & 91,85 & 46,83 & $21.481,73$ & 4,3321 \\
\hline 51 & Croatia & 86,98 & 86,37 & 87,59 & $21.408,55$ & 4,3306 \\
\hline 52 & Panama & 78 & 86,15 & 69,85 & $21.334,94$ & 4,3291 \\
\hline 53 & Antigua and Barbuda & 62,55 & 88,43 & 36,67 & $20.777,61$ & 4,3176 \\
\hline 54 & Uruguay & 73,98 & 95,48 & 52,48 & $20.046,93$ & 4,3020 \\
\hline 55 & Mauritius & 70,85 & 94,56 & 47,13 & $19.548,64$ & 4,2911 \\
\hline 56 & Argentina & 79,84 & 94,5 & 65,18 & $18.479,44$ & 4,2667 \\
\hline 57 & Bulgaria & 83,4 & 85,18 & 81,62 & $17.709,08$ & 4,2482 \\
\hline 58 & Mexico & 73,59 & 77,58 & 69,61 & $16.831,12$ & 4,2261 \\
\hline 59 & Gabon & 67,37 & 75,06 & 59,68 & $16.786,00$ & 4,2249 \\
\hline 60 & Belarus & 82,3 & 87,37 & 77,24 & $16.742,26$ & 4,2238 \\
\hline 61 & Iraq & 63,97 & 64,19 & 63,75 & $16.086,92$ & 4,2065 \\
\hline 62 & Azerbaijan & 83,78 & 82,96 & 84,6 & $15.994,01$ & 4,2040 \\
\hline 63 & Thailand & 69,54 & 71,61 & 67,46 & $15.681,81$ & 4,1954 \\
\hline 64 & Montenegro & 78,89 & 89,6 & 68,19 & $15.658,11$ & 4,1947 \\
\hline 65 & Turkmenistan & 70,24 & 70,44 & 70,04 & $15.648,37$ & 4,1945 \\
\hline 66 & Barbados & 54,96 & 86,83 & 23,09 & $15.588,27$ & 4,1928 \\
\hline 67 & Botswana & 70,72 & 72,37 & 69,07 & $15.513,44$ & 4,1907 \\
\hline 68 & Costa Rica & 80,03 & 91,15 & 68,91 & $15.401,49$ & 4,1876 \\
\hline 69 & China & 65,1 & 59,41 & 70,79 & $14.400,89$ & 4,1584 \\
\hline 70 & Dominican Republic & 75,32 & 78,91 & 71,73 & $14.098,88$ & 4,1492 \\
\hline 71 & Brazil & 78,9 & 87,14 & 70,67 & $14.023,69$ & 4,1469 \\
\hline 72 & Algeria & 70,28 & 76,07 & 64,5 & $13.974,67$ & 4,1453 \\
\hline 73 & Serbia & 78,67 & 83,35 & 73,98 & $13.720,09$ & 4,1374 \\
\hline 74 & Colombia & 75,93 & 82,2 & 69,66 & $13.124,32$ & 4,1181 \\
\hline 75 & Suriname & 68,58 & 83,81 & 53,34 & $13.113,86$ & 4,1177 \\
\hline 76 & Macedonia & 78,02 & 84,71 & 71,33 & $13.054,78$ & 4,1158 \\
\hline 77 & Lebanon & 69,14 & 71,69 & 66,6 & $12.974,17$ & 4,1131 \\
\hline 78 & Grenada & 63,28 & 89,79 & 36,78 & $12.910,99$ & 4,1110 \\
\hline 79 & South Africa & 70,52 & 76,66 & 64,38 & $12.260,17$ & 4,0885 \\
\hline 80 & Maldives & 57,1 & 87,43 & 26,77 & $12.235,55$ & 4,0876 \\
\hline 81 & Peru & 72,95 & 78,39 & 67,51 & $12.071,59$ & 4,0818 \\
\hline 82 & Albania & 74,38 & 84,74 & 64,03 & $11.424,63$ & 4,0578 \\
\hline 83 & Sri Lanka & 65,55 & 71,07 & 60,02 & $11.417,26$ & 4,0576 \\
\hline 84 & Mongolia & 64,39 & 67,86 & 60,92 & $11.328,48$ & 4,0542 \\
\hline 85 & Bosnia and Herzegovina & 63,28 & 87,09 & 39,48 & $11.179,35$ & 4,0484 \\
\hline 86 & Indonesia & 65,85 & 76,82 & 54,88 & $10.764,55$ & 4,0320 \\
\hline 87 & Tunisia & 77,28 & 81,1 & 73,46 & $10.752,02$ & 4,0315 \\
\hline 88 & Ecuador & 66,58 & 85,61 & 47,55 & $10.462,44$ & 4,0196 \\
\hline 89 & Egypt & 66,45 & 69,97 & 62,93 & $10.319,26$ & 4,0136 \\
\hline 90 & Dominica & 73,25 & 86,53 & 59,98 & $10.174,04$ & 4,0075 \\
\hline 91 & Namibia & 70,84 & 69,72 & 71,96 & $9.812,41$ & 3,9918 \\
\hline
\end{tabular}

DE GRUYTER OPEN
Studia Universitatis "Vasile Goldis" Arad. Economics Series Vol 27 Issue 3/2017 ISSN: 1584-2339; (online) ISSN: 2285 - 3065

Web: publicatii.uvvg.ro/index.php/studiaeconomia.Pages $15-32$ 


\section{STUDIA UNIVERSITATIS ECONOMICS SERIES}

"Vasile Goldiş" Western University of Arad

Neagu O., Ardelean D.I., Lazăr V. (2017)

How is environmental performance associated with economic growth? A world cross-country analysis

\begin{tabular}{|c|c|c|c|c|c|c|}
\hline 92 & Georgia & 64,96 & 78,12 & 51,81 & $9.267,30$ & 3,9670 \\
\hline 93 & Paraguay & 70,36 & 81,14 & 59,58 & $8.877,61$ & 3,9483 \\
\hline 94 & Fiji & 75,29 & 86,6 & 63,99 & $8.862,74$ & 3,9476 \\
\hline 95 & Jordan & 72,24 & 76,67 & 67,81 & $8.389,54$ & 3,9237 \\
\hline 96 & Jamaica & 77,02 & 86,96 & 67,09 & $8.190,00$ & 3,9133 \\
\hline 97 & Armenia & 81,6 & 81,76 & 81,44 & $8.174,37$ & 3,9125 \\
\hline 98 & Bhutan & 64,99 & 69,14 & 60,84 & $8.105,80$ & 3,9088 \\
\hline 99 & El Salvador & 68,07 & 77,25 & 58,88 & $7.990,00$ & 3,9025 \\
\hline 100 & Belize & 73,55 & 83,39 & 63,71 & $7.831,45$ & 3,8938 \\
\hline 101 & Swaziland & 60,63 & 62,03 & 59,23 & $7.733,81$ & 3,8884 \\
\hline 102 & Ukraine & 79,69 & 85,74 & 73,63 & $7.668,06$ & 3,8847 \\
\hline 103 & Guatemala & 69,64 & 71,78 & 67,49 & $7.366,77$ & 3,8673 \\
\hline 104 & Morocco & 74,18 & 74,28 & 74,09 & $7.265,85$ & 3,8613 \\
\hline 105 & Guyana & 71,14 & 83,53 & 58,76 & $7.248,23$ & 3,8602 \\
\hline 106 & Philippines & 73,7 & 75,14 & 72,27 & $7.236,47$ & 3,8595 \\
\hline 107 & Bolivia & 71,09 & 78,91 & 63,26 & $6.707,96$ & 3,8266 \\
\hline 108 & India & 53,58 & 47,99 & 59,17 & $6.092,65$ & 3,7848 \\
\hline 109 & Cape Verde & 51,98 & 69,32 & 34,64 & $6.074,75$ & 3,7835 \\
\hline 110 & Uzbekistan & 63,67 & 78,49 & 48,85 & $6.038,87$ & 3,7810 \\
\hline 111 & Angola & 51,32 & 55,18 & 47,46 & $6.024,73$ & 3,7799 \\
\hline 112 & Viet Nam & 58,5 & 68,24 & 48,76 & $5.955,26$ & 3,7749 \\
\hline 113 & Samoa & 70,2 & 83,33 & 57,06 & $5.882,15$ & 3,7695 \\
\hline 114 & Laos & 50,29 & 51,18 & 49,39 & $5.734,59$ & 3,7585 \\
\hline 115 & Nigeria & 58,27 & 53,01 & 63,53 & $5.438,92$ & 3,7355 \\
\hline 116 & Myanmar & 48,98 & 51,82 & 46,14 & $5.351,55$ & 3,7285 \\
\hline 117 & Tonga & 66,86 & 84,42 & 49,3 & $5.332,47$ & 3,7269 \\
\hline 118 & Congo & 59,56 & 57,72 & 61,4 & $5.301,40$ & 3,7244 \\
\hline 119 & Nicaragua & 64,19 & 72,37 & 56,02 & $5.136,84$ & 3,7107 \\
\hline 120 & Moldova & 76,69 & 75,3 & 78,08 & $4.944,34$ & 3,6941 \\
\hline 121 & Pakistan & 51,42 & 52,73 & 50,11 & $4.866,16$ & 3,6872 \\
\hline 122 & Honduras & 69,64 & 74,19 & 65,09 & $4.392,27$ & 3,6427 \\
\hline 123 & Sudan & 42,25 & 49,63 & 34,87 & $4.385,05$ & 3,6420 \\
\hline 124 & Ghana & 58,89 & 54,47 & 63,31 & $3.980,20$ & 3,5999 \\
\hline 125 & Zambia & 66,06 & 59,53 & 72,59 & $3.636,06$ & 3,5606 \\
\hline 126 & Mauritania & 46,31 & 50,1 & 42,53 & $3.572,28$ & 3,5529 \\
\hline 127 & Cambodia & 51,24 & 58,8 & 43,67 & $3.462,84$ & 3,5394 \\
\hline 128 & Cote d'Ivoire & 59,89 & 56,41 & 63,36 & $3.448,14$ & 3,5376 \\
\hline 129 & Bangladesh & 41,77 & 40,36 & 43,18 & $3.319,35$ & 3,5211 \\
\hline 130 & Kyrgyz Republic & 73,13 & 77,73 & 68,54 & $3.291,97$ & 3,5175 \\
\hline 131 & Cameroon & 57,13 & 54,47 & 59,78 & $3.045,92$ & 3,4837 \\
\hline 132 & Sao Tome and Principe & 48,28 & 66,92 & 29,64 & $2.993,38$ & 3,4762 \\
\hline 133 & Kenya & 62,49 & 58,6 & 66,39 & $2.925,60$ & 3,4662 \\
\hline 134 & Vanuatu & 57,74 & 66,63 & 48,85 & $2.856,48$ & 3,4558 \\
\hline 135 & Lesotho & 47,17 & 56,74 & 37,59 & $2.808,24$ & 3,4484 \\
\hline 136 & Tajikistan & 73,05 & 71,41 & 74,7 & $2.762,59$ & 3,4413 \\
\hline 137 & Tanzania & 58,34 & 47,25 & 69,43 & $2.583,28$ & 3,4122 \\
\hline 138 & Senegal & 63,73 & 60,36 & 67,1 & $2.380,39$ & 3,3766 \\
\hline 139 & Yemen & 49,79 & 57,63 & 41,94 & $2.325,07$ & 3,3664 \\
\hline 140 & Nepal & 50,21 & 46,16 & 54,26 & $2.287,72$ & 3,3594 \\
\hline 141 & Solomon Islands & 46,92 & 61,55 & 32,3 & $2.072,71$ & 3,3165 \\
\hline 142 & Benin & 43,66 & 44,75 & 42,57 & $2.009,96$ & 3,3032 \\
\hline
\end{tabular}

DE GRUYTER OPEN
Studia Universitatis "Vasile Goldis" Arad. Economics Series Vol 27 Issue 3/2017 ISSN: 1584-2339; (online) ISSN: 2285 - 3065

Web: publicatii.uvvg.ro/index.php/studiaeconomia.Pages 15 - 32 
STUDIA UNIVERSITATIS ECONOMICS SERIES

"Vasile Goldiş" Western University of Arad

Neagu O., Ardelean D.I., Lazăr V. (2017)

How is environmental performance associated with economic growth? A world cross-country analysis

\begin{tabular}{|l|l|r|r|r|r|c|}
\hline 143 & Mali & 41,48 & 38,36 & 44,59 & $1.962,69$ & 3,2929 \\
\hline 144 & Kiribati & 60,48 & 73,64 & 47,33 & $1.897,81$ & 3,2783 \\
\hline 145 & Zimbabwe & 59,25 & 64,28 & 54,22 & $1.859,94$ & 3,2695 \\
\hline 146 & Chad & 37,83 & 28,46 & 47,21 & $1.845,91$ & 3,2662 \\
\hline 147 & Rwanda & 50,34 & 51,88 & 48,79 & $1.773,75$ & 3,2489 \\
\hline 148 & Afghanistan & 37,5 & 52,92 & 22,08 & $1.739,58$ & 3,2404 \\
\hline 149 & Uganda & 57,56 & 51,71 & 63,4 & $1.713,85$ & 3,2340 \\
\hline 150 & Haiti & 43,28 & 50,01 & 36,55 & $1.653,96$ & 3,2185 \\
\hline 151 & Ethiopia & 45,83 & 36,96 & 54,69 & $1.608,29$ & 3,2064 \\
\hline 152 & Burkina Faso & 43,71 & 37,65 & 49,77 & $1.594,58$ & 3,2026 \\
\hline 153 & The Gambia & 52,09 & 54,69 & 49,49 & $1.565,80$ & 3,1947 \\
\hline 154 & Guinea-Bissau & 48,2 & 42,67 & 53,72 & $1.466,27$ & 3,1662 \\
\hline 155 & Comoros & 49,2 & 54,68 & 43,72 & $1.411,15$ & 3,1496 \\
\hline 156 & Madagascar & 37,1 & 32,69 & 41,51 & $1.396,09$ & 3,1449 \\
\hline 157 & Togo & 46,1 & 42,96 & 49,24 & $1.382,11$ & 3,1405 \\
\hline 158 & Sierra Leone & 45,98 & 41,05 & 50,91 & $1.365,87$ & 3,1354 \\
\hline 159 & Guinea & 55,4 & 46,26 & 64,54 & $1.215,03$ & 3,0846 \\
\hline 160 & Mozambique & 41,82 & 31,24 & 52,4 & $1.128,28$ & 3,0524 \\
\hline 161 & Malawi & 49,69 & 47,53 & 51,86 & $1.083,97$ & 3,0350 \\
\hline 162 & Niger & 37,48 & 25,11 & 49,86 & 906,99 & 2,9576 \\
\hline 163 & Liberia & 43,42 & 46,88 & 39,97 & 753,56 & 2,8771 \\
\hline 164 & Dem. Rep. Congo & 42,05 & 33,85 & 50,25 & 742,31 & 2,8706 \\
\hline 165 & Burundi & 43,37 & 38,94 & 47,81 & 721,18 & 2,8580 \\
\hline 166 & Central African Republic & 46,46 & 37,29 & 55,62 & 647,88 & 2,8115 \\
\hline
\end{tabular}

GRUYTER OPEN
Studia Universitatis "Vasile Goldis" Arad. Economics Series Vol 27 Issue 3/2017 ISSN: 1584-2339; (online) ISSN: 2285 - 3065

Web: publicatii.uvvg.ro/index.php/studiaeconomia.Pages 15 - 32 